\title{
Vera M. Kutzinski, The Worlds of Langston Hughes: Modernism and Translation in the Americas
}

\section{Frédéric Sylvanise}

\section{(2) OpenEdition}

\section{Journals}

Electronic version

URL: https://journals.openedition.org/transatlantica/7224

DOI: $10.4000 /$ transatlantica.7224

ISSN: 1765-2766

\section{Publisher}

Association française d'Etudes Américaines (AFEA)

Electronic reference

Frédéric Sylvanise, "Vera M. Kutzinski, The Worlds of Langston Hughes: Modernism and Translation in the Americas", Transatlantica [Online], 2 | 2014, Online since 04 March 2015, connection on 31 January 2023. URL: http://journals.openedition.org/transatlantica/7224 ; DOl: https://doi.org/10.4000/ transatlantica.7224

This text was automatically generated on 31 January 2023.

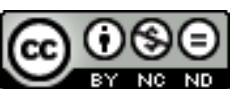

Creative Commons - Attribution-NonCommercial-NoDerivatives 4.0 International - CC BY-NC-ND 4.0 https://creativecommons.org/licenses/by-nc-nd/4.0/ 


\title{
Vera M. Kutzinski, The Worlds of Langston Hughes: Modernism and Translation in the Americas
}

\author{
Frédéric Sylvanise
}

\section{REFERENCES}

KUTZINSKI, Vera M., The Worlds of Langston Hughes: Modernism and Translation in the Americas, Ithaca, NY: Cornell University Press, 2012, 344 pages, ISBN-10 : 080147826X, paperback, 27 \$ $28 €$

Vera Kutzinski's study begins with a grim observation: Langston Hughes is one of the most underrated modernist poets. Part of this injustice, according to the author, is due to the fact that most critics considered the influence of his poetry in the Englishspeaking world only. Further, many have classified his work either as racial or social but rarely as modernist, rejecting his most committed poems on formal grounds. Worst of all, more often than not Hughes's poetry has lazily and inaccurately been labeled simple, maintaining him outside the club of supposedly more complex modernists. To remedy these deficiencies, Kutzinski undertakes something that has never been done before with such amplitude and accuracy-evaluating the ambiguity and the complexity of Hughes's art by examining the gaps engendered by the translations/ mistranslations of his poems, especially in Latin America. Relying on two different Latin terms to define translation (2) - "the act of moving oneself (translatio)" and that of "leading or carrying someone or something across some sort of divide (traductio)" she first studies how Hughes's autobiographical works drew on different languages and cultures thanks to the poet's travels around the globe, making his literary language a mixture of different foreign idioms and references (on this point at least Kutzinski is not a pioneer, since Daniel T. McGee at Johns Hopkins University wrote a remarkable $\mathrm{PhD}$ on the subject in 1998 which, though centered on Hughes's poetry rather than his autobiographies, surprisingly is not mentioned in the bibliography). Then the author 
examines numerous Hughes translations by Latin American poets and Hughes's own translations of Hispanic poets. Lastly she explores the ways his poetry was diverted into an ideological tool against him during the McCarthy hearings of 1953 (a telling example of mistranslation).

2 The first chapter, "Nomad Heart," explores misconceptions regarding his two autobiographies, The Big Sea (1940) and I Wonder as I Wander (1956). Kutzinski wishes they had been read with more depth since they are not as transparent as they appear to be. She notes that his biographers have systematically taken them at face value, thus ignoring Hughes's jazzman-like unpredictability: “Hughes's autobiographies should be read as we read his verse: by paying attention not to the obvious narrative but to the elements that disrupt that line, throw it off course" (19). Arguing convincingly that Hughes uses a game of masks in The Big Sea, she draws a parallel between his work, the tradition of the picaresque novel, and Shakespeare's Tempest, casting new light on these neglected writings and going considerably further than Henry Louis Gates's readings, based on his theory of signifyin', which ignore Hughes's potential European intertext. The author further sees Hughes as an early theorist of the diaspora, borrowing from and absorbing many different languages, including Spanish, French and Russian, to create a "plurilingual, heterocultural poetics" (55).

While the first chapter of the book was conceived as a series of intuitions and hypotheses illustrated by a few examples from Hughes's autobiographies, in the next three, entitled "Southern Exposures: Hughes in Spanish," "Buenos Aires Blues: Modernism in the Creole City," and "Havana Vernaculars: The Cuba Libre Project," Kutzinski resorts to a more systematic method (which at times risks becoming bogged down in detail, especially for frustrated non-Spanish-speakers). By comparing different translations of the same poems, or by analyzing specific choices by translators and anthologists, she establishes that Hughes's poetry was received according to the translators' geopolitical/cultural situations and interests: "I argue that several distinct regional or international discourses, notably anti-US American imperialism, socialism, and modernism, provided the triple lenses through which Hughes's poems were refracted in the Hispanic Americas" (59). For example, in 1930s Cuba, both translators and anthologists used Hughes's poems as a way to further their anti-imperialist agendas, carefully avoiding those poems that could unveil contradictions at home, especially when dealing directly with color. In the conclusion to chapter 2, Kutzinski consequently invites critics to avoid drawing easy parallels between all Black people from the American continent. What is valid in North America may not be true in the Caribbean or South American context.

In chapter 3, dedicated to the poet's reception in Argentina, Kutzinksi uses detailed readings to prove that writer and translator Jorge Luis Borges's choices tended more towards the aesthetic than the political-he proved to be Hughes's best translator in terms of poetic language, but clearly toned down the poet's most radical stances, showing that translation necessarily implies foregrounding selected aspects of the original texts, particularly when the latter bear such political weight as Hughes's poems from the 1930s and 1940s did. Conversely, Hughes's translations of Hispanic poems studied in chapter 4 (those of long-time Cuban friend Nicolas Guillen, cotranslated with Ben Frederick Carruthers as Cuba Libre) show misconceptions and inaccuracies not unlike those found in the poet's least convincing translations of his own poems. What is at stake, unsurprisingly, is Hughes's knowledge of the Spanish 
language rather than any kind of poetic sense. Hughes's mastery of form is sometimes hampered by lexical and cultural gaps since, in a way, he too served his own agenda when dealing with foreign texts. In both cases, and in many others presented in the book, Kutzinski subtly demonstrates the intricacy of the translatio and the traductio sides of translation work. When tackling the question of the vernacular and its poetic use as a counterpart to more 'standard' language, she proves with remarkable acuity that translation is first at work inside the poem: "Vernacular, especially when transferred from an oral to literary setting, already implies translation..." (163). In other words, what Hughes found himself confronting, sometimes inextricably, was not only the passage from Spanish to English, but also the passage from one Spanish idiom to another. Showing both the 'vertical' and the 'horizontal' aspects of translation is one of the book's greatest achievements.

Hughes scholars will be even more fascinated by the final chapter of the book entitled "Back in the USSA: Joe McCarthy's Mistranslations." In 2003, the transcripts of the 1953 secret hearings preceding the public hearings of the poet by Senator McCarthy and the other members of the infamous U.S. Senate Permanent Subcommittee on Government Operations were released. Kutzinski, unlike Hughes's official biographers (principally Arnold Rampersad, whose tremendous work retrospectively appears incomplete and even somewhat flawed), had access to these documents and what they reveal is quite a shock. Much has been said on Hughes's public capitulation faced with people who obviously pressured him to the point of making him a traitor in the eyes of young 1960s activists and poets. What they did not know was how Hughes, before renouncing his socialist ideals of the 1930s and 1940s, argued, sometimes bitterly, with his interviewers a few days before the public hearings, using irony and insolent questions to defend himself as best he could: "The fact that the Hughes of the executive session is anything but cooperative makes it necessary to reassess the prevalent picture of Hughes as a 'friendly' McCarthy witness..." (186). Going through the whole sessions, Kutzinski patiently analyzes them and shows that McCarthy and Hughes did not speak the same language-when his interviewers force him to identify with the socialist speakers of his poems, Hughes constantly distinguishes between poet and persona, between opinion and fictional discourse. Censors did not have a problem with Hughes's poetry so to speak, they simply had no idea what poetry is. For anyone interested in the idea of committed literature, this study is a tour-de-force. Though apparently sidestepping a little from the preceding chapters, the author never loses her perspective, dissecting the committee's mistranslations of Hughes's texts with both rigor and evident enthusiasm.

6 Vera Kutzinski concludes her fine study by wishing for a "deautomatization" (224) of translation and a complete redefinition of literary American studies. She has clearly shown the way. 


\section{AUTHORS}

FRÉDÉRIC SYLVANISE

Université Paris 13-Nord 